\title{
ASSESSMENT OF THE RELATIONSHIP BETWEEN ECONOMIC GROWTH, ENERGY CONSUMPTION, CARBON EMISSIONS AND RENEWABLE ENERGY SOURCES IN THE V4 COUNTRIES
}

\author{
Jana Chovancová* \\ University of Prešov, Faculty of \\ Management and Business, \\ Prešov, Slovakia \\ jana.chovancova@unipo.sk

\section{Eva Litavcová} \\ University of Prešov, Faculty of \\ Management and Business, \\ Prešov, Slovakia \\ eva.litavcova@unipo.sk \\ Tetiana Shevchenko \\ Sumy National Agrarian \\ University, The Faculty of \\ Economics and Management, \\ Sumy, Ukraine \\ tetiana.shevchenko@snau.edu.ua \\ * corresponding author
}

Received: November 2021

Revision: November 2021

Accepted: December 2021

\begin{abstract}
The aim of this paper is to assess the long-term and short-term relationships between economic growth, energy consumption, $\mathrm{CO}_{2}$ emissions and the share of energy produced from renewable energy sources in the $\mathrm{V} 4$ countries in the period 1992-2019. The autoregressive distributed lag (ARDL) bounds testing methodology was applied for each of the examined variables as a dependent variable. The ARDL bounds reliably confirmed long-run cointegration between carbon emissions, energy consumption, economic growth, and renewables in Czechia, Slovakia, and Poland. Economic growth has a significant impact on carbon emissions in the long run in all of these three countries. Energy consumption has a significant impact on carbon emissions in the long-run in Poland; however, renewables significantly impact carbon emissions in Czechia and Slovakia. Understanding the interrelationships between the variables examined is essential for making informed and responsible decisions on climate and energy policies, strategies and actions in individual countries.
\end{abstract}

Keywords: energy consumption, economic growth, $\mathrm{CO}_{2}$ emissions, renewable energy sources, decarbonisation, carbon-neutral economy, $\mathrm{V} 4$ countries

JEL Classification: O13, P18, Q43

DOI: $10.54933 / \mathrm{jmbrp}-2021-13-2-3$

Chovancová, J., Litavcová, E. \& Shevchenko, T. (2021). Assessment of the relationship between economic growth, energy consumption, $\mathrm{CO} 2$ emissions and renewable energy sources in the V4 countries. Journal of Management and Business: Research and Practice, 13(2). doi: 10.54933/jmbrp-2021-13-2-3 


\section{Introduction}

Energy has been inextricably linked to human development since its beginning. It fueled and accelerated the industrial revolution more than two hundred years ago, and up to this day, it supports a highly complex interplay of human needs, desires, activities, and technologies. Although energy is fundamental for economic growth, its production and consumption are responsible for a number of negative environmental impacts. One of the most challenging global issues is anthropogenic greenhouse gas emissions, coming mainly from fossil fuel combustion for energy production. Rising concentrations of greenhouse gas emissions (especially $\mathrm{CO}_{2}$ ) in the atmosphere are causing air temperature increases, resulting in climate change. According to the IPCC report, human-induced global warming reached approximately $1^{\circ} \mathrm{C}$ above pre-industrial levels and in the absence of efficient mitigation policies aimed at a sharp decline in greenhouse gas emission, global warming is likely to surpass $1,5^{\circ} \mathrm{C}$ sometime between 2030 and 2045 (IPCC, 2021). These unprecedented changes pose a threat to humanity and ecosystems in the form of various natural disasters, rapid weather changes, health problems, threats to biodiversity, etc.

Although EU greenhouse gas emissions are gradually being reduced, the energy sector is still the largest producer of these emissions. Until 2009, the second-largest share of greenhouse gas (GHG) emissions was accounted for by the industrial sector, whose emissions fell after that year and were replaced by those of the transport sector. As $\mathrm{CO}_{2}$ accounts for up to $80 \%$ of total greenhouse gas emissions, it is considered the primary driver of climate change (EEA, 2021; Tiseo, 2021). An overview of GHG emissions by sector, accounting for the largest share of EU GHG emissions, is shown in Figure 1.

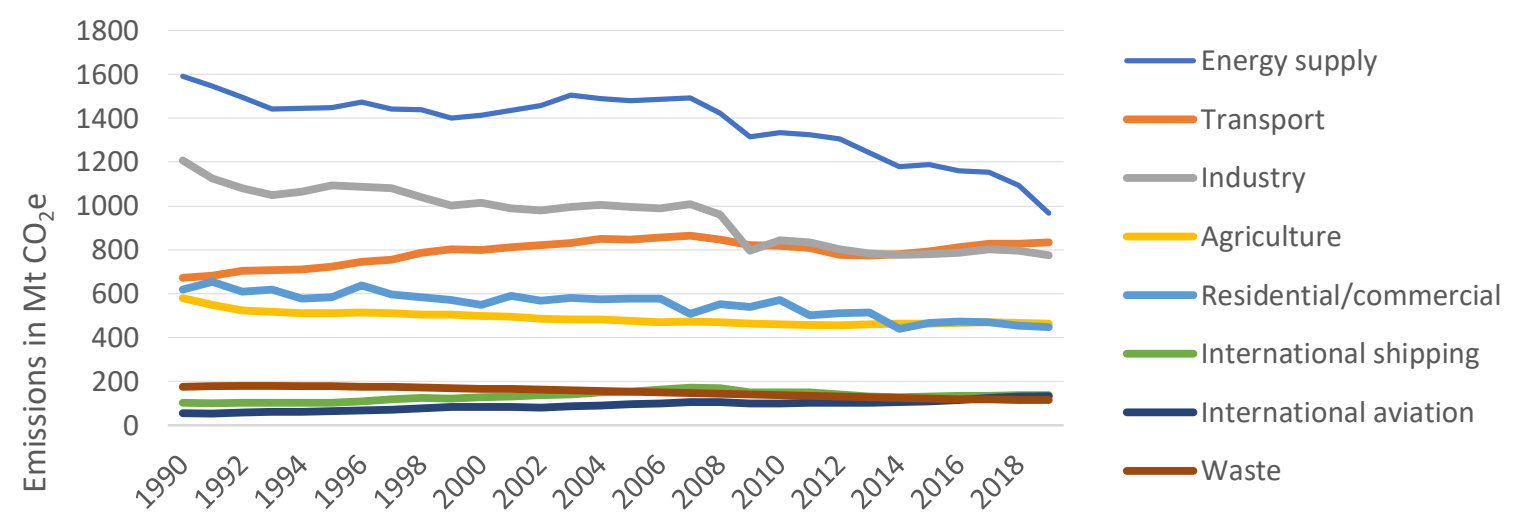

Figure 1. Annual greenhouse gas emissions in the European Union from 1990 to 2019, by sector (in million metric tons of $\mathrm{CO}_{2}$-equivalent)

Source: own processing, based on Eurostat

The adverse effects of rising carbon dioxide levels in the atmosphere have become a central topic in global discussion on transition to a carbon-neutral, green economy (EC, 2020; OECD, 2014; United Nations, 2015). The importance of these issues is also reflected in the European Union's political and strategic decisions. In December 2019, the EU introduced an ambitious proposal to make the bloc climate-neutral by 2050 (EC, 2019). This objective is at the heart of the European Green Deal and is in line with the EU's commitment to global climate action under the Paris Agreement. However, not all countries are proponents of green growth visions. Especially in V4 countries, Poland and the Czech Republic are reluctant to reduce greenhouse gases at the expense of economic development. The aim of the paper is to discuss the link between economic growth, energy consumption, $\mathrm{CO}_{2}$ emissions and the share of renewable energy sources in energy production in the V4 countries. Assessing the relationship between the four variables will shed light on the driving forces of $\mathrm{CO}_{2}$ emission production and the potential mitigation effect of renewables.

The paper is structured as follows. First, the theoretical background and overview of the previous empirical research carried out in this area are presented. Section 2 outlines the research methodology and data used. In the third section, the results of analysis are presented, followed by the fourth section discussing the results and limitations of the research. The last section concludes the paper. 


\section{Theoretical background}

Numerous studies focus on investigating the relationship between economic growth, energy use and GHG emissions, testing the validity of the Environmental Kuznets Curve (EKC) hypothesis that postulates an inverted U-shaped relationship between environmental degradation and per capita income in different countries/regions.

The use of EKC can be observed on two levels: theoretical and empirical. Theoretical studies devoted to the EKC can be traced to the early 1990s. One of the seminal works in this field was a study on measures to improve air quality (Grossman \& Krueger, 1991). Other theoretical works from this period include (Panayotou, 1994) and (Shafik, 1994), in which the authors provide the earliest and most detailed explanation of the possible relationship between the degree of environmental degradation and the level of economic development expressed by the EKC (Yandle et al., 2004).

The empirical research on EKC focused mainly on two areas. The first group consists of studies examining the validity of the EKC for various indicators of environmental pollution (e.g., Diao et al., 2009; Hilton \& Levinson, 1998; Kaika \& Zervas, 2013; Sapkota \& Bastola, 2017; Sarkodie, 2018; Selden \& Song, 1994). These studies confirm the EKC's hypothesis that although economic growth leads to an increase in emissions at the beginning of economic development, over time these emissions may decrease due to various technological and structural changes in the economy. The second group of studies focuses on turning points for specific pollutants and countries (e.g. Apergis \& Ozturk (2015); Gawande et al. (2000); Özokcu \& Özdemir (2017); Park \& Lee (2011); Patel et al. (1995); Zaim \& Taskin (2000). Numerous studies on extensive material empirically demonstrate the validity of the EKC for various pollutants and processes in the environmental sphere (air, water, deforestation), as well as for economic sectors and countries. The validity of the EKC hypothesis, confirmed by many empirical studies, has led to its application in complex international research (e.g. Bölük \& Mert (2014); Chovancová \& Vavrek (2019); Cole et al. (1997); Miglietta et al. (2017); Sarkodie \& Strezov (2018); Shafiei \& Salim (2014); Waqih et al. (2019)).

However, the relationship between economic growth and environmental impacts is not straightforward, and other variables enter into this relationship. The United Nations report (UN, 2021), which assesses the achievement of sustainable development goals, emphasizes that energy consumption is responsible for $60 \%$ of total global greenhouse gas emissions. In light of this, the interaction between environmental degradation, energy consumption, and economic growth has been a frequently discussed issue in the energy economics literature in the last few decades. Ang (2007) first examined the dynamic relationship between pollutant emissions, energy consumption and economic development in France between 1960 and 2000. Ang points out that if these three variables are intensely interconnected, omitting one of them can cause serious problems in empirical analysis. Tiba \& Omri (2017) conducted a comprehensive literature review on the relationship between energy, the environment, and economic growth at the level of individual countries and regions. After Ang, different authors explore the interrelationships of the three variables for different countries: e.g. Soytas et al. (2007) focused on the USA, Zhang \& Cheng (2009) analyzed the situation in China, Halicioglu (2009) in Turkey, Acaravci \& Ozturk (2010) analyzed nineteen EU Member States, Vavrek \& Chovancová (2020) examined energy performance of EU28, Baloch et al. (2019) performed the analysis of BRICS countries, Ozcan \& Tzeremes (2020) surveyed 27 OECD countries and Litavcová \& Chovancová (2021) performed the analysis of Danube region countries.

Researchers and practitioners point to renewable energy sources as a possible avenue for rebalancing economic growth, and environmental quality. Hence, the development of renewable energy has attracted the attention of many countries, including the EU member states. Therefore, this study examines the interrelationship between economic growth, energy consumption, greenhouse gas emissions, and the share of energy from renewable sources as a possible tool for mitigating negative environmental impacts.

\section{Data and methodology}

\section{Data}

The paper examines the relationship between economic growth (GDP per capita), energy consumption per capita, $\mathrm{CO}_{2}$ emissions per capita, and the share of renewable energy sources in the Visegrad Group (V4) countries (Czech Republic, Hungary, Poland, and Slovakia) in the period 19922019. The data were retrieved from the World Bank's databases (GDP per capita in constant 2010 US \$) 
and Eurostat (energy consumption per capita in $\mathrm{kWh}, \mathrm{CO}_{2}$ per capita in tons, renewable energy sources in \% of gross final energy consumption).

The descriptive statistics are presented in Table 1, where the mean, minimum and maximum values, and standard deviation are calculated for each of the V4 countries. Stata 15.1 was used as the software tool for data processing and statistical analysis.

Table 1. Descriptive Statistics, $n=28$

\begin{tabular}{|c|c|c|c|c|c|}
\hline & & $\begin{array}{l}\text { Czechia } \\
\mathrm{CZ}\end{array}$ & $\begin{array}{l}\text { Slovakia } \\
\text { SK }\end{array}$ & $\begin{array}{l}\text { Hungary } \\
\text { HU }\end{array}$ & $\begin{array}{l}\text { Poland } \\
\text { PL }\end{array}$ \\
\hline \multirow[t]{4}{*}{ GDP per capita } & Mean & 29978,67 & 21194,98 & 20461,56 & 22901,04 \\
\hline & Min & 20760,05 & 11690,94 & 10714,66 & 15854,16 \\
\hline & $\operatorname{Max}$ & 40696,31 & 31871,33 & 33120,52 & 32553,52 \\
\hline & Std.Dev. & 6156,32 & 6523,68 & 6604,11 & 4807,33 \\
\hline \multirow[t]{4}{*}{ Per capita $\mathrm{CO} 2$ emissions } & Mean & 11,590 & 7,508 & 8,639 & 5,428 \\
\hline & Min & 9,430 & 6,020 & 7,090 & 4,350 \\
\hline & $\operatorname{Max}$ & 13,969 & 9,040 & 9,940 & 6,143 \\
\hline & Std.Dev. & 1,292 & 0,897 & 0,602 & 0,521 \\
\hline \multirow[t]{4}{*}{ Energy consumption per capita } & Mean & 46878,68 & 37557,10 & 29018,28 & 27758,85 \\
\hline & Min & 43317,38 & 32904,99 & 25954,79 & 24560,78 \\
\hline & $\operatorname{Max}$ & 51297,28 & 41549,63 & 32106,32 & 30463,14 \\
\hline & Std.Dev. & 2284,56 & 2684,21 & 1582,11 & 1373,81 \\
\hline \multirow[t]{4}{*}{ Renewables (\% sub energy) } & Mean & 2,569 & 6,515 & 2,342 & 1,593 \\
\hline & Min & 0,808 & 2,529 & 0,380 & 0,198 \\
\hline & Max & 5,183 & 9,700 & 6,182 & 4,017 \\
\hline & Std.Dev. & 1,645 & 1,583 & 2,133 & 1,360 \\
\hline
\end{tabular}

Source: own processing, based on Eurostat and World Bank

The Czech Republic leads the table in GDP per capita, per capita $\mathrm{CO}_{2}$ emissions, and energy consumption per capita. The share of renewables in this country is the second-lowest, with a maximum of $5,183 \%$.

Energy consumption per capita reaches the highest number in Slovakia, but renewables are also in the highest place among the surveyed countries. However, all of these countries lag far behind the EU average of $19.7 \%$ in 2019 in renewable energy production.

Significant heterogeneity of individual variables can be observed in some countries, which is reflected in the high value of standard deviation. Hungary and Slovakia are examples of countries where the signifficant growth of GDP can be observed. However, despite significant GDP growth, except for the Czech Republic, all countries in the survey group are below the EU average GDP per capita, which was 35,070.328 USD in December 2019.

\section{Methodology}

The theoretical and empirical literature indicates that economic growth, $\mathrm{CO}_{2}$ emissions, and energy consumption are bound together, as well as that employing renewable energy sources has a mitigating effect on the production of greenhouse gas emissions. We work with such data from four countries, collectively known as the Visegrad Group. All variables related to economic growth, energy consumption, $\mathrm{CO}_{2}$ emissions, and renewables are utilized in natural logarithmic form. We use the abbreviations $\log \mathrm{GDPt}, \log \mathrm{CO} 2 \mathrm{t}, \log \mathrm{ECt}$, and $\log \mathrm{RESt}$ to denote their values at time $\mathrm{t}$.

This research utilizes the unit root test of Dickey \& Fuller (Dickey \& Fuller, 1979), and bound test for cointegration of Pesaran et al. (Pesaran et al., 2001) which is extended by critical values and approximate p-values of Kripfganz and Schneider (Kripfganz \& Schneider, 2020).

Some time series are bound together due to equilibrium forces even though the individual time series might move considerably. We focus on four of such series, $\log \mathrm{GDPt}, \log \mathrm{CO} 2 \mathrm{t}, \log \mathrm{ECt}$, and $\log \mathrm{RESt}$. The methodology to determine this long-term impact and significance of considered variables uses an 
autoregressive distributed lag (ARDL) modelling approach, widely developed by Pesaran and Shin (Pesaran \& Shin, 1999) and Pesaran, Shin and Smith (Pesaran et al., 2001), which allows establishing whether there is cointegration between the variables, even if they are of a different order. For the purpose of efficient estimation of the model coefficients, an optimal lag order is obtained with model selection criteria such as the Akaike or Schwarz information criterion. However, for testing purposes, it is of primary concern that the error term is free of serial correlation. Once a conclusion from the test is drawn, a more parsimonious model can be estimated (Kripfganz \& Schneider, 2020).

An additional advantage of its estimation is that it allows obtaining unbiased and efficient parameters when the presence of endogeneity and serial correlation problems is suspected. In addition, it is more appropriate for estimating short and long term on small samples, which is also our case.

For the first, the stationarity test was done using the Augmented Dickey-Fuller (ADF) test to ensure that none of the series employed in this study is I(2) (Litavcová \& Chovancová, 2021).

To find a cointegration relationship between economic growth, $\mathrm{CO}_{2}$ emissions, energy consumption, and renewables employed ARDL $\left(p, q_{1}, q_{2}, q_{3}\right)$ model can be expressed as follows:

$$
y_{t}=c_{0}+\sum_{i=1}^{p} \phi_{i} y_{t-i}+\sum_{i=0}^{q_{1}} \beta_{1, i} x_{1, t-i}+\sum_{i=0}^{q_{2}} \beta_{2, i} x_{2, t-i}+\sum_{i=0}^{q_{3}} \beta_{3, i} x_{3, t-i}+u_{t}
$$

where $p \geq 1, q_{1} \geq 0, q_{2} \geq 0, q_{3} \geq 0$ are optimal lag orders for dependent variable $y$ and three independent variables $x_{1}, x_{2}$ and $x_{3} ; \varphi$-s and $\beta$-s are coefficients; $c_{o}$ is a constant; $u_{t}$ is the error term. Independent variables allowed to be I(o) or I(1) or cointegrated. For each of the considered countries,

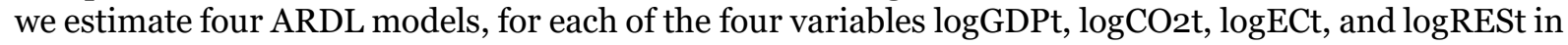
the position of the explained variable.

The existence of a long-run cointegrating relationship can be tested based on the error correction representation. A bounds testing procedure allows to find out this relationship regardless the variables are integrated of order zero or one, I(o) or I(1), respectively. In this way, if the value calculated for the F-statistic is above the critical value of the upper limit, the null hypothesis of no cointegration is rejected and the existence of a long-term relationship is concluded. On the contrary, if the F-statistic is below the critical value of the lower limit, it implies the absence of cointegration (Pesaran et al., 2001).

However, where there is cointegration according to Pesaran et al. (2001), the model can be represented by an error correction form. The error-correction form of the ARDL model separates the adjustment coefficient to deviations from long-run equilibrium, long-run coefficients, and short-run coefficients. The model can be written as follows:

$$
\begin{aligned}
& \Delta y_{t}=c_{0}-\alpha\left(y_{t-1}-\theta_{1} x_{1, t}-\theta_{2} x_{2, t}-\theta_{3} x_{3, t}\right)+ \\
& +\sum_{i=1}^{p-1} \psi_{i} \Delta y_{t-i}+\sum_{i=0}^{q_{1}-1} \gamma_{1, i} \Delta x_{1, t-i}+\sum_{i=0}^{q_{2}-1} \gamma_{2, i} \Delta x_{2, t-i}+\sum_{i=0}^{q_{3}-1} \gamma_{3, i} \Delta x_{3, t-i}+u_{t}
\end{aligned}
$$

where $\alpha$ is the speed adjustment coefficient; $\theta$-s are long-run, $\psi$-s and $\gamma$-s are short-run coefficients. To confirm the long-term relationship, the coefficient $\alpha$ is expected to be negative and statistically significant. Likewise, to ensure the validity of the results of the cointegration test, the tests of heteroscedasticity, autocorrelation and normality of the residuals are applied. In line with Odugbesan and Rjoub (Odugbesan \& Rjoub, 2020), we also employed Breusch-Godfrey Serial Correlation LM (Lagrange multiplier) test to investigate a serial correlation in each equation, and Breusch-PaganGodfrey heteroskedasticity test was also used to determine that the model is free from the heteroskedasticity problem. To test the normality of residuals, the SW test was used. Finally, as (Pesaran et al., 2001) recommend, the cumulative sum of recursive residuals (CUSUM) should be applied in determining the stability of the ARDL model.

\section{Results}

\section{Unit Root Test}

The unit root test was applied to determine the stationarity of our data set. This is necessary to avoid an unpredictable outcome in our time series analysis (Odugbesan \& Rjoub, 2020). There exist several tests of stationarity. In this analysis, one of them, particularly the augmented Dickey-Fuller unitroot test (ADF) on the level and on the first difference was employed. The three-time series are stationary already at level, i.e. $\log R E S$ in Slovakia, and $\log \mathrm{CO} 2$ in Poland and in Hungary. In the case of logGDP and $\operatorname{logEC}$, the time series of all countries have unit root at a level and are stationary after the first differences. Also variables $\log \mathrm{CO} 2$ and $\log \mathrm{RES}$ meet the requirements for further analysis because they 
are stationary at the first difference. None of the variables employed in the analysis is integrated at I(2) so as not to violate the assumptions of ARDL (Pesaran et al., 2001).

Table 2 Augmented Dickey-Fuller unit-root test

\begin{tabular}{|c|c|c|c|c|c|c|c|c|}
\hline & $\operatorname{logGDP}$ & & $\log \mathrm{CO} 2$ & & $\log E C$ & & logRES & \\
\hline Country & Level & $\begin{array}{l}\text { First } \\
\text { difference }\end{array}$ & Level & $\begin{array}{l}\text { First } \\
\text { difference }\end{array}$ & Level & $\begin{array}{l}\text { First } \\
\text { difference }\end{array}$ & Level & $\begin{array}{l}\text { First } \\
\text { difference }\end{array}$ \\
\hline Czechia & -0.567 & $-3.449^{* *}$ & -1.541 & $-7.003^{* * *}$ & -1.465 & $-4.689^{* * *}$ & -0.784 & $-5 \cdot 978^{* * *}$ \\
\hline Slovakia & -1.216 & $-3.919^{* *}$ & -1.679 & $-8.092^{* * * *}$ & -1.091 & $-7.407^{* * * *}$ & $-4.175^{* * * *}$ & $-6.119^{* * *}$ \\
\hline Poland & -1.517 & $-3.154^{*}$ & $-3.238^{*}$ & $-9.731^{* * *}$ & -1.230 & $-4.408^{* * *}$ & -0.050 & $-4.421^{* * *}$ \\
\hline Hungary & 0.121 & $-3.374^{*}$ & $-3.119^{*}$ & $-8.756^{* * *}$ & -1.710 & $-4.441^{* * *}$ & -0.505 & $-3.447^{* *}$ \\
\hline
\end{tabular}

Note: The significance of the ADF test is indicated by an asterisks in the table where “*”, “**”, “***” denotes $5 \%, 1 \%$, and $0.1 \%$ significance level.

\section{ARDL bound testing for cointegration}

The results of the bound test show F-values and the lower and upper critical F-values of Kripfganz \& Schneider (Kripfganz \& Schneider, 2020) at 5\% are captured in table 3.

Table 3. The ARDL Bound Testing for cointegration with Kripfganz and Schneider (Kripfganz \& Schneider, 2020) critical values and approximate $p$-values

\begin{tabular}{|c|c|c|c|c|c|c|}
\hline Country & Variable & $\begin{array}{c}\text { F- } \\
\text { statistic }\end{array}$ & $\begin{array}{c}\mathrm{I}(0) \\
\text { bound } \\
(5 \%)\end{array}$ & $\begin{array}{c}\text { I(1) } \\
\text { bound } \\
(5 \%)\end{array}$ & $\begin{array}{c}\text { Co- } \\
\text { integration }\end{array}$ & Decision \\
\hline \multirow[t]{4}{*}{$\mathbf{C Z}$} & $\log \mathrm{CO} 2$ & 12.355 & 3.979 & 5.729 & Yes & error correction model \\
\hline & $\operatorname{logLEC}$ & 4.953 & 3.967 & 5.660 & Yes & $\begin{array}{l}\text { error correction model } \\
\text { (in 10\% cv) }\end{array}$ \\
\hline & $\log G D P$ & 1.744 & 3.929 & 5.454 & No & short-run model \\
\hline & $\operatorname{logRES}$ & 5.718 & 3.992 & 5.798 & Yes & error correction model \\
\hline \multirow[t]{4}{*}{ SK } & $\log \mathrm{CO} 2$ & crashed & & & Yes & error correction model \\
\hline & $\operatorname{logLEC}$ & 2.652 & 3.941 & $5 \cdot 523$ & No & short-run model \\
\hline & $\log G D P$ & crashed & & & Yes & error correction model \\
\hline & $\operatorname{logRES}$ & 5.737 & 3.916 & 5.385 & Yes & error correction model \\
\hline \multirow[t]{4}{*}{ PL } & $\log \mathrm{CO} 2$ & 21.169 & 3.904 & 5.317 & Yes & error correction model \\
\hline & $\log L E C$ & 11.189 & 3.979 & 5.729 & Yes & error correction model \\
\hline & $\log G D P$ & 4.830 & 3.904 & $5 \cdot 317$ & No & short-run model \\
\hline & $\operatorname{logRES}$ & 3.350 & 3.941 & 5.523 & No & short-run model \\
\hline \multirow[t]{4}{*}{ HU } & $\log \mathrm{CO}_{2}$ & crashed & & & No & short-run model \\
\hline & logLEC & crashed & & & No & short-run model \\
\hline & $\log$ GDP & 5.630 & 3.916 & $5 \cdot 385$ & No & short-run model (due t \\
\hline & logRES & 6.121 & 3.954 & 5.591 & Yes & error correction model \\
\hline
\end{tabular}

In the case of Czechia, if $\mathrm{CO}_{2}$ is the dependent variable, then the cointegration among $\mathrm{CO}_{2}$, GDP, energy consumption and renewables was detected. This indicates that there are possibilities of a longrun relationship among the variables. So there will be necessary to estimate the error correction model to determine the speed of adjustment in case there is a shock. The same applies for the energy consumption and renewables as dependent variables. Based on the result of the ARDL bounds test for cointegration, for GDP as a dependent variable, it is necessary to apply only the ARDL short-run model. Here, the cointegration was not confirmed.

In the case of Poland, when $\mathrm{CO}_{2}$ and energy consumption are considered ependent variables, the cointegration with the other three variables was revealed and the error correction model was performed to determine the significance of the long-run relationship and the speed of adjustment. For GDP and renewables in the position of dependent variable, there is no cointegration, i.e. only a shortrun model was applied.

As for Slovakia, the result from the bounds test shows a cointegration when renewables is the dependent variable, while in the case of $\log \mathrm{CO}_{2}$ and $\log \mathrm{GDP}$ bound test failed due to the small number of data. When examining both models, i.e. long-run and short-run, based on the results we decided for the error correction model. 
Considering Hungary, the same situation occurred. Similarly, as in Slovakia, we decided for the ARDL (short-run) models for variables $\mathrm{CO}_{2}$ and energy consumption because the time series were too short. In this country, the selection of the error correction model was verified by a bound test only for renewables as the dependent variable. The bound test showed the suitability of the short-run model for variable $\log G D P$.

\section{Estimates for causal relationship}

For Czechia, Slovakia and Poland, the error correction model was estimated to determine the long-run relationship and the speed of adjustment due to the long-run relationship among $\mathrm{CO}_{2}$ emissions, economic growth, energy consumption, and renewables. As can be seen in Table 4, the economic growth and $\mathrm{CO}_{2}$ emissions have a stable long-run causal relationship in all of these three countries. The Error Correction Term (ECT) coefficients for these countries are -2.41, -1.04, and -1.47; all of them are negative and statistically significant. The first of them is too low - this implies that it will take a long period for the system to adjust back to equilibrium in the presence of shock and equilibrium will be adjusted in a dampening manner (Odugbesan \& Rjoub, 2020). Diagnostic tests reveal that models for Czechia and Slovakia have a serious problem with serial correlation and the model for Poland has a problem with the normality of residuals. As the time series were too short, a better model could not be found. If there is no validity problem, the result implies that in the presence of shock, it will take a long time to return back to equilibrium as a result of the high speed of adjustment in these countries (Odugbesan \& Rjoub, 2020).

The results in Table 5 reveal statistically significant short-run causality running from economic growth to $\mathrm{CO}_{2}$ emissions in Slovakia and Hungary. The short-run causality running from energy consumption to $\mathrm{CO}_{2}$ emissions has been demonstrated in the same countries, i.e. Slovakia and Hungary, and the short-run causality running from renewables to $\mathrm{CO}_{2}$ emissions has been demonstrated in Czechia, Slovakia and Hungary. The results for Hungary are the product of a valid short-run model.

The variables that contribute to the economic growth in the $\mathrm{V}_{4}$ countries are depicted in Table 4. The results reveal that only in one country, i.e. Slovakia, the $\mathrm{CO}_{2}$ emissions, and renewables have a long-run relationship with economic growth. But, as diagnostic tests reveal, there is a problem with serial correlation in this model.

The results shown in Table 5 indicate that there is a short-run causality running from $\mathrm{CO}_{2}$ emissions to economic growth in three countries: Czechia, Slovakia and Poland, whereas the other two variables, energy consumption and renewables, have short-run causality to economic growth in Slovakia, Poland and Hungary.

The existence of cointegration, i.e. long-run relationship among energy consumption, economic growth, $\mathrm{CO}_{2}$ emissions and renewables was present in Czechia and Poland, as it follows from Table 4. The ECT coefficient for Czechia is -0.47 and the long-run relationship is stable and valid. This implies that the energy consumption converges to the long-run equilibrium by $47 \%$ in one period with the speed adjustment via the channel of economic growth, $\mathrm{CO}_{2}$ emissions, and renewables (Türsoy, 2017). As in the model for Poland, random errors are not normally distributed; the model is not valid. However, a better model could not be found. Statistically significant short-run causality running from economic growth to energy consumption was present only in Czechia, as it follows from Table 5. The short-run causality running from $\mathrm{CO}_{2}$ emissions to energy consumption has been proved in Poland and Hungary, and the short-run causality running from renewables to energy consumption has been demonstrated in Slovakia, Poland, and Hungary.

On the variables that contribute to the increase of renewables use for energy production in the V4 countries, the results depicted in Table 4 reveal that in Czechia, Slovakia, and Hungary economic growth, $\mathrm{CO}_{2}$ emissions, and energy consumption a long-run relationship with renewables is present, with good validity of all three long-run models. Table 4 shows that economic growth and $\mathrm{CO}_{2}$ emissions have a stable long-run causal relationship with renewables in Czechia and Hungary. However, energy consumption has a stable long-run causal relationship with renewables only in Slovakia. The ECT coefficient of a stable long-run relationship for Slovakia is -0.84 . Therefore, this implies that the renewables converge to the long-run equilibrium by $84 \%$ in one period with the speed adjustment via the channel of economic growth, $\mathrm{CO}_{2}$ emissions, and energy consumption (Hobijn et al., 1998).

Moreover, the results shown in Table 5 reveal that there is also a short-run causality running from economic growth to renewables in Hungary, running from $\mathrm{CO}_{2}$ emissions to renewables in Czechia and Hungary. The significant short-run relationship running from energy consumption to renewables has not been demonstrated in any of the $\mathrm{V}_{4}$ countries. This implies that energy consumption in the V4 countries does not cause renewable energy consumption.

The diagnostic tests mentioned in the previous chapter was used for verification of the validity of each model. It was found that 9 of all 16 models are valid and relevant and can support responsible 
and evidence-based decisions and policy making. Also, the testing of the stability of the models revealed that they all fall within the $5 \%$ significance level boundary.

Table 4 Long-run statistic and Diagnostic test

\section{Part A: Long run statistics}

\begin{tabular}{|c|c|c|c|c|c|c|}
\hline & $\begin{array}{l}\text { Dependent } \\
\text { variable }\end{array}$ & $\log G D P t$ & $\log \mathrm{CO} 2 \mathrm{t}$ & $\log L E C t$ & logLRESt & ECT \\
\hline \multirow[t]{4}{*}{$\mathbf{C Z}$} & $\triangle \log C O 2 t$ & $0.14^{*}$ & & -0.15 & $-0.22 * * *$ & $-2.41 * * *$ \\
\hline & $\triangle \log L E C t$ & $0.56^{* *}$ & 0.37 & & $-0.16^{*}$ & $-0.47^{* *}$ \\
\hline & $\Delta \log G D P t$ & & & & & \\
\hline & $\Delta \log R E S t$ & $0.74^{* *}$ & $-4.36^{* * *}$ & -0.71 & & $-1.99 * *$ \\
\hline \multirow[t]{4}{*}{ SK } & $\Delta \log C O 2 t$ & $-0.51 * * *$ & & 0.04 & $0.33^{*}$ & $-1.04^{* * *}$ \\
\hline & $\Delta \operatorname{logLECt}$ & & & & & \\
\hline & $\Delta \log G D P t$ & & $-1.90 * * *$ & 0.11 & $0.69 * *$ & $0.32 * *$ \\
\hline & $\Delta \log R E S t$ & -0.01 & -0.50 & $-1.98^{* *}$ & & $-0.84^{* * *}$ \\
\hline \multirow[t]{4}{*}{ PL } & $\Delta \log C O 2 t$ & $-0.16^{*}$ & & $0.78^{* * *}$ & 0.02 & $-1.47^{* * *}$ \\
\hline & $\triangle \operatorname{logLECt}$ & $0.15^{* *}$ & $0.89 * * *$ & & -0.001 & $-1.61^{* * *}$ \\
\hline & $\Delta \log G D P t$ & & & & & \\
\hline & $\Delta \log R E S t$ & & & & & \\
\hline \multirow[t]{4}{*}{ HU } & $\Delta \log C O 2 t$ & & & & & \\
\hline & $\Delta \operatorname{logLECt}$ & & & & & \\
\hline & $\Delta \log G D P t$ & & & & & \\
\hline & $\Delta \log R E S t$ & $4.68^{* * *}$ & $-5.44 * *$ & 3.64 & & $-0.67 * * *$ \\
\hline
\end{tabular}

Part B: Diagnostic tests

Dependent Normality Shapiro Ser. Corr Homoskedasticity Stability
variable Wilk p-value bgodfrey imtest white

\begin{tabular}{|c|c|c|c|c|c|}
\hline \multirow{5}{*}{$\mathbf{C Z}$} & & & p-value & p-value & \\
\hline & $\Delta \log C O 2 t$ & 0.20 & $0.01^{* *}$ & 0.40 & stable \\
\hline & $\triangle \operatorname{logLECt}$ & 0.81 & 0.14 & 0.40 & stable \\
\hline & $\Delta \log G D P t$ & 0.31 & 0.68 & 0.76 & stable \\
\hline & $\Delta \log R E S t$ & 0.29 & 0.09 & 0.40 & stable \\
\hline \multirow[t]{4}{*}{ SK } & $\Delta \log C O 2 t$ & 0.72 & $0.02^{*}$ & 0.40 & stable \\
\hline & $\Delta \operatorname{logLECt}$ & 0.96 & 0.93 & 0.40 & stable \\
\hline & $\Delta \log G D P t$ & 0.34 & $0.02^{*}$ & 0.40 & stable \\
\hline & $\Delta \log R E S t$ & 0.07 & 0.32 & 0.26 & stable \\
\hline \multirow[t]{4}{*}{ PL } & $\Delta \log C O 2 t$ & $0.02^{*}$ & 0.34 & 0.52 & stable \\
\hline & $\Delta \operatorname{logLECt}$ & $0.01^{*}$ & 0.58 & 0.40 & stable \\
\hline & $\Delta \log G D P t$ & 0.85 & $0.04^{*}$ & 0.40 & stable \\
\hline & $\Delta \log R E S t$ & $0.04^{*}$ & 0.58 & 0.40 & stable \\
\hline \multirow[t]{4}{*}{ HU } & $\Delta \log C O 2 t$ & 0.98 & 0.47 & 0.40 & stable \\
\hline & $\Delta \operatorname{logLECt}$ & 0.86 & 0.20 & 0.40 & stable \\
\hline & $\Delta \log G D P t$ & 0.13 & $0.01^{*}$ & 0.40 & stable \\
\hline & $\Delta \log R E S t$ & 0.15 & 0.64 & 0.40 & stable \\
\hline
\end{tabular}

Note: The significance of the coefficients is indicated by an asterisks in the tables where “*”, “***, “****" denotes $5 \%, 1 \%$, and $0.1 \%$ significance level. 
Table 5. Short-run statistic

\begin{tabular}{|c|c|c|c|c|c|c|c|c|c|c|c|}
\hline & Part A & $\Delta \operatorname{logGD}$ & & & & & $\triangle \log C O 2$ & & & & \\
\hline & Dependent variable & $\mathbf{t}$ & t-1 & t-2 & $t-3$ & $t-4$ & $\mathbf{t}$ & t-1 & t-2 & $t-3$ & $t-4$ \\
\hline \multirow[t]{4}{*}{$\mathbf{C Z}$} & $\Delta \log C O 2 t$ & & & & & & & $0.89^{* * *}$ & $0.58^{* *}$ & & \\
\hline & $\Delta \operatorname{logLECt}$ & 0.25 & $-0.79^{* * *}$ & 0.12 & $-0.53^{*}$ & & & & & & \\
\hline & $\Delta \log G D P t$ & & $0.39^{*}$ & & & & $0.21^{*}$ & & & & \\
\hline & $\Delta \operatorname{logRESt}$ & & & & & & $6.03^{* *}$ & $3.25^{*}$ & $2.12^{*}$ & & \\
\hline \multirow[t]{4}{*}{ SK } & $\Delta \log C O 2 t$ & $2.08^{* * *}$ & $1.86^{* * *}$ & & & & & $-0.72^{* * * *}$ & $-0.66^{* * *}$ & $-0.38^{* * *}$ & \\
\hline & $\Delta \operatorname{logLECt}$ & -0.17 & & & & & 0.18 & & & & \\
\hline & $\Delta \log G D P t$ & & $-1.09^{* * *}$ & & & & 0.01 & $0.46^{* * *}$ & $0.41^{* * * *}$ & $0.23^{* *}$ & \\
\hline & $\Delta \operatorname{logRESt}$ & & & & & & & & & & \\
\hline \multirow[t]{4}{*}{ PL } & $\Delta \log C O 2 t$ & & & & & & & & & & \\
\hline & $\Delta \operatorname{logLECt}$ & & & & & & $-1.07^{* * *}$ & $-0.57^{* *}$ & -0.18 & & \\
\hline & $\Delta \log G D P t$ & & $0.76^{* * *}$ & $-0.49^{*}$ & -0.19 & & $-0.14^{*}$ & -0.02 & -0.17 & $-0.20^{*}$ & $-0.20^{* * *}$ \\
\hline & $\Delta \operatorname{logRESt}$ & -16.1 & $13 \cdot 3$ & -6.39 & -5.83 & & -2.01 & 0.84 & -1.63 & -3.09 & -3.46 \\
\hline \multirow[t]{6}{*}{ HU } & $\Delta \log C O 2 t$ & 1.89 & $-2.28^{*}$ & $2.77^{* * *}$ & $-1.25^{*}$ & $-1.56^{*}$ & & $-0.53^{*}$ & & & \\
\hline & $\Delta \operatorname{logLECt}$ & 0.46 & & & & & $0.26^{* *}$ & $0.29^{* * *}$ & $0.41^{* * * *}$ & $0.19^{* * *}$ & \\
\hline & $\Delta \log G D P t$ & & $0.62^{*}$ & $-0.64^{*}$ & $0.52^{*}$ & & 0.07 & -0.04 & -0.18 & & \\
\hline & $\Delta \operatorname{logRESt}$ & $-9.21^{* *}$ & -3.41 & & & & $1.49^{*}$ & & & & \\
\hline & Part B & $\Delta \operatorname{logEC}$ & & & & & $\triangle \operatorname{logRES}$ & & & & \\
\hline & Dependent variable & $\mathbf{t}$ & t-1 & t-2 & $t-3$ & $t-4$ & $\mathbf{t}$ & $t-1$ & t-2 & $t-3$ & $t-4$ \\
\hline \multirow[t]{4}{*}{$\mathbf{C Z}$} & $\Delta \log C O 2 t$ & & & & & & $0.36^{* *}$ & $0.34^{* * *}$ & $0.29^{* * *}$ & $0.12 *$ & \\
\hline & $\Delta \operatorname{logLECt}$ & & $0.38 *$ & & & & & & & & \\
\hline & $\Delta \log G D P t$ & 0.29 & & & & & 0.01 & & & & \\
\hline & $\Delta \operatorname{logRESt}$ & -1.93 & & & & & & $1.18^{* *}$ & $1.09^{* *}$ & 0.45 & \\
\hline \multirow[t]{4}{*}{ SK } & $\Delta \log C O 2 t$ & -0.02 & -0.29 & $-0.69^{* *}$ & $-0.57^{* *}$ & & $-0,33^{* *}$ & $-0,34^{* * *}$ & $-0.23^{* *}$ & $-0.13^{* * *}$ & \\
\hline & $\Delta \operatorname{logLECt}$ & & -0.26 & & & & -0.06 & 0.04 & $-0.14^{*}$ & & \\
\hline & $\Delta \operatorname{logGDPt}$ & 0.03 & 0.18 & $0.45^{* *}$ & $0.34^{* * *}$ & & $0.21^{* * *}$ & $0.22^{* * *}$ & $0.14^{* * * *}$ & $0.08^{* *}$ & \\
\hline & $\Delta \operatorname{logRESt}$ & 1.26 & & & & & & & & & \\
\hline \multirow[t]{4}{*}{ PL } & $\Delta \log C O 2 t$ & & & & & & & & & & \\
\hline & $\Delta \operatorname{logLECt}$ & & $0.62^{* *}$ & $0.42^{*}$ & & & $-0.08^{*}$ & & & & \\
\hline & $\Delta \operatorname{logGDPt}$ & 0.05 & $0.20^{*}$ & $0.38^{* * *}$ & -0.05 & 0.26 & -0.03 & 0.04 & 0.07 & $-0.06^{*}$ & $-0.05^{*}$ \\
\hline & $\Delta \operatorname{logRESt}$ & -1.43 & 2.17 & 6.30 & -1.60 & 3.23 & & 0.86 & $1.52^{*}$ & -0.85 & -1.07 \\
\hline \multirow[t]{4}{*}{ HU } & $\Delta \log C O 2 t$ & $1.85^{* *}$ & $1.55^{* *}$ & -0.11 & -0.65 & $1.87^{* * *}$ & 0.05 & $-0.23^{* *}$ & $0.34^{* *}$ & $-0.33^{* *}$ & $0.42^{* * *}$ \\
\hline & $\Delta \operatorname{logLECt}$ & & -0.28 & $-0.49^{* *}$ & -0.34 & $-0.22^{*}$ & $0.03^{*}$ & $0.03^{*}$ & -0.01 & $0.04^{*}$ & -0.04 \\
\hline & $\Delta \log G D P t$ & 0.15 & -0.26 & 0.35 & 0.22 & $-0.24^{*}$ & -0.02 & $0.06^{*}$ & $-0.09^{* * *}$ & $0.07^{*}$ & $-0.10^{* *}$ \\
\hline & $\Delta \operatorname{logRESt}$ & & & & & & & $0.48^{*}$ & & & \\
\hline
\end{tabular}

Note: The significance of the coefficients is indicated by an asterisks in the tables where “*”, “**”, “***” denotes 5\%, 1\%, and $0.1 \%$ significance level.

\section{Discussion}

As shown in Tables 4 and 5, the analysis of the long-run and short-run relationships among four variables economic growth, energy consumption, carbon emissions, and renewables in the V4 countries reveals contrasting findings. To better understand these complex relationships, we have captured them graphically in table 6.

From the long-run perspective, the results for Czechia show the existence of a bi-directional relationship between renewables and carbon emissions, indicating that these two variables are jointly determined and affect each other, which supports the feedback hypothesis (Aydin, 2019). Economic growth has a positive effect on energy consumption, $\mathrm{CO}_{2}$ and renewables. This implies that conservation policies aimed at energy efficiency and promoting the use of renewable energy sources do not influence economic growth (Menegaki \& Tugcu, 2016). A bi-directional relationship between renewables and carbon emissions is also present in the short run.

Bi-directional long-run causality between economic growth and carbon emissions was found only in the case of Slovakia. This relationship was also confirmed in the study by Al-Mulali \& Che Sab (2018) for South Korea. Renewables have a positive effect on GDP and $\mathrm{CO}_{2}$, where uni-directional longrun causality can be observed. However, energy consumption negatively affects the share of renewable energy. Similarly, a bi-directional relationship between economic growth and carbon emissions is present in terms of a short-run relationship. In the short run, the negative effect of energy consumption 
on the production of $\mathrm{CO}_{2}$ emissions is also evident. Renewables contribute to a decline in $\mathrm{CO}_{2}$ emissions and have a positive effect on the economic growth of the country in the short-term perspective. The wider adoption of renewable energy sources in this case brings multiple benefits - it improves the quality of the environment and public health and supports economic development. In a broader perspective, it presents a possible path for the $\mathrm{V}_{4}$ countries in meeting the climate neutrality targets set at the EU level (Hafner \& Raimondi, 2020).

Table 6 Relationship between variables

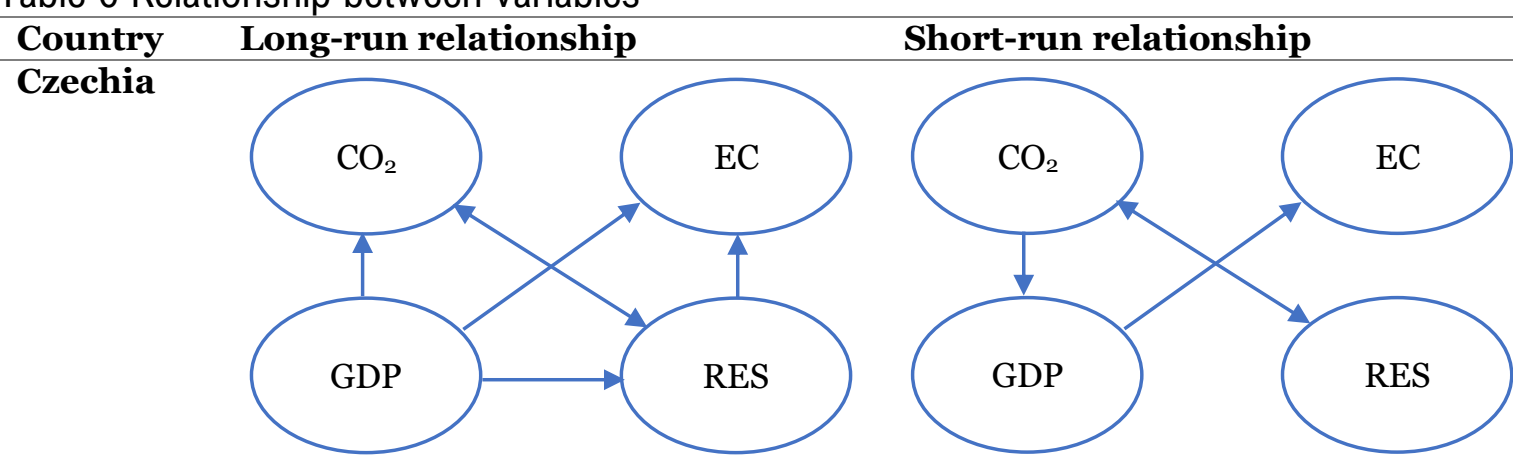

\section{Slovakia}
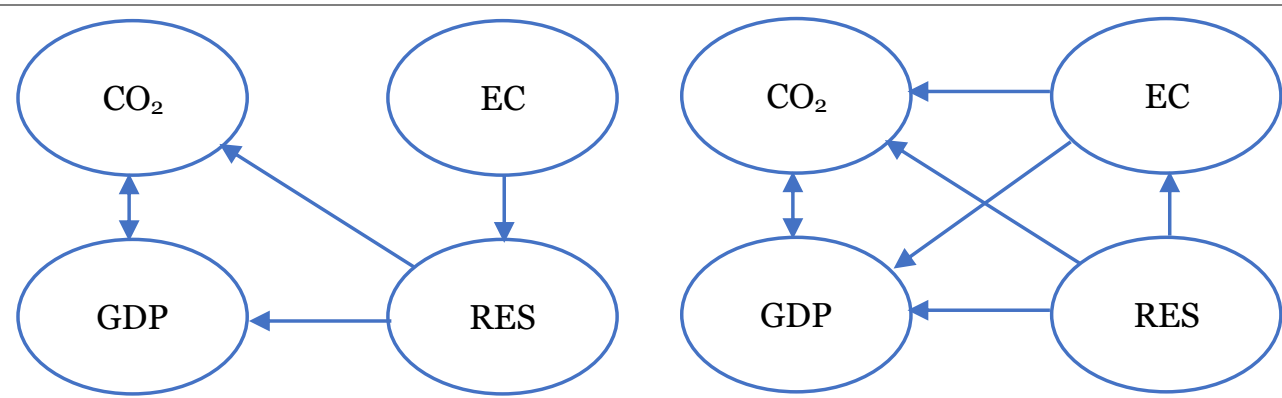

\section{Poland}
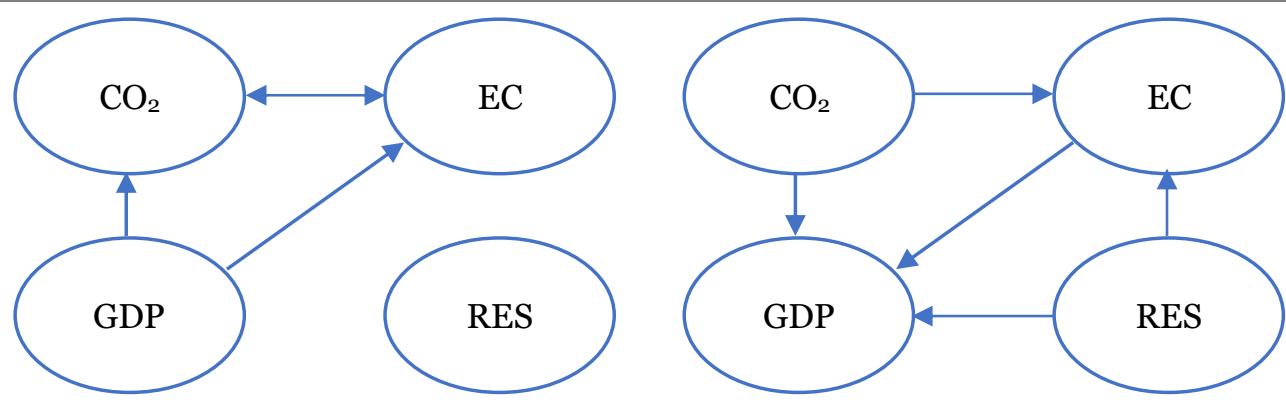

\section{Hungary}
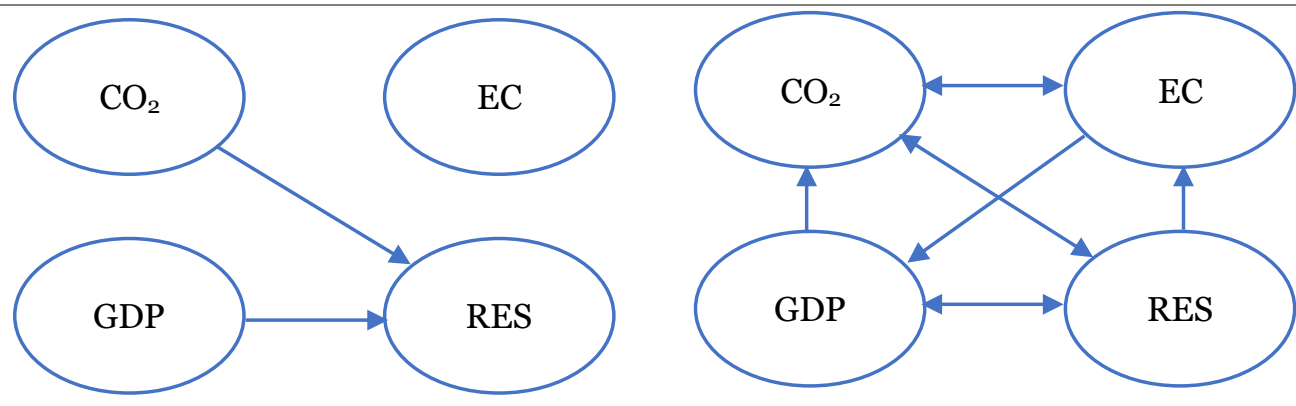

Note 1:

Uni-directional long-run relationship

Bi-directional long-run relationship

Note 2: GDP - gross domestic product, $\mathrm{CO}_{2}$ - carbon dioxide, EC - energy consumption, RES renewable energy sources. 
Results for Poland show a positive uni-directional relationship between GDP and energy consumption, suggesting that an increase in GDP causes an increase in energy consumption in the long run. Similar results were achieved by Ozturk et al. (2010) in their study, where this relationship applied to low-income countries. The introduction of decarbonisation and energy efficiency measures will play an important role in this country. The negative uni-directional relationship between economic growth and $\mathrm{CO}_{2}$ emissions implies that with a growing economy, $\mathrm{CO}_{2}$ emissions decrease. This may be due to technological advancement and/or structural changes in the economy. This fact supports the EKC hypothesis, suggesting that at a certain level of economic development countries invest more in environmental measures, which is reflected in improving the quality of the environment. A feedback effect is evident between energy consumption and carbon emissions. The neutrality hypothesis applies to renewables, where there is no relationship between other variables in the long run, which complies with the findings of Menegaki (2011) for EU 27 countries. In the short run, $\mathrm{CO}_{2}$ emissions affect negatively the economic growth of the country.

From a long-term perspective, we can observe only two uni-directional relations in the case of Hungary: the positive effect of economic growth on renewable energy sources and the negative effect of $\mathrm{CO}_{2}$ on renewables. However, short-run relations are more complex. Feedback effects can be observed between renewables and $\mathrm{CO}_{2}$ emissions, economic growth and renewables, as well as $\mathrm{CO}_{2}$ emissions and energy consumption, implying that these variables affect each other. In the short term, unidirectional relationships can be observed running from GDP to $\mathrm{CO}_{2}$ emissions, from energy consumption to GDP, and from renewables to energy consumption.

\section{Conclusions}

In the context of escalating global environmental pressures, it has become increasingly clear that Europe's prevailing model of economic development - based on steadily growing resource use and harmful emissions - cannot be sustained in the long term. Therefore, one of the priorities of the European Union and the $\mathrm{V}_{4}$ countries that are the subject of our research is the transition to a resourceefficient and a low-carbon society.

This study examines the long- and short-run relationships and causality between economic growth, energy consumption, and carbon emissions in $\mathrm{V}_{4}$ countries, including renewable energy, in a multivariate framework.

The ARDL bounds reliably confirm long-run cointegration between $\mathrm{CO}_{2}$ emissions, energy consumption, economic growth, and renewables in Czechia, Slovakia, and Poland. Economic growth impacts significantly the levels of $\mathrm{CO}_{2}$ emissions in the long run in all of these three countries. Also, energy consumption is a strong driver for carbon emissions in the long-run in Poland. However, renewables significantly impact carbon emissions in Czechia and Slovakia. In the short run, the impact of economic growth and energy consumption is significant in Slovakia and Hungary. The impact of renewables in Czechia, Slovakia and Hungary is also significant. Likewise, when examining cointegration between carbon emissions, energy consumption, economic growth, and renewables in the short run, a significant contribution of $\mathrm{CO}_{2}$ emissions to energy consumption in Poland and Hungary was detected as a result of four models.

The analysis confirmed the existence of heterogeneous relationships between the examined variables in the individual V4 countries. Revealing the interrelationships between these variables represents an important knowledge base for decision-makers and other stakeholders responsible for the formulation of new and revision of existing climate and energy policies.

\section{Acknowledgements}

This research has been supported by Scientific Grant Agency of the Ministry of Education, Science, Research and Sport of the Slovak Republic and the Slovak Academy of Sciences within the project 1/0508/21. 


\section{References}

Acaravci, A., \& Ozturk, I. (2010). On the relationship between energy consumption, $\mathrm{CO} 2$ emissions and economic growth in Europe. Energy. https://doi.org/10.1016/j.energy.2010.07.009

Al-Mulali, U., \& Che Sab, C. N. B. (2018). Electricity consumption, CO2 emission, and economic growth in the Middle East. Energy Sources, Part B: Economics, Planning, and Policy, 13(5), 257-263.

Ang, J. B. (2007). CO2 emissions, energy consumption, and output in France. Energy Policy. https://doi.org/10.1016/j.enpol.2007.03.032

Apergis, N., \& Ozturk, I. (2015). Testing environmental Kuznets curve hypothesis in Asian countries. Ecological Indicators. https://doi.org/10.1016/j.ecolind.2014.11.026

Aydin, M. (2019). Renewable and non-renewable electricity consumption-economic growth nexus: evidence from OECD countries. Renewable Energy, 136, 599-606.

Balcilar, M., Ozdemir, Z. A., Tunçsiper, B., Ozdemir, H., \& Shahbaz, M. (2020). On the nexus among carbon dioxide emissions, energy consumption and economic growth in G-7 countries: new insights from the historical decomposition approach. Environment, Development and Sustainability. https://doi.org/10.1007/s10668-019-00563-6

Baloch, M. A., Mahmood, N., \& Zhang, J. W. (2019). Effect of natural resources, renewable energy and economic development on $\mathrm{CO} 2$ emissions in BRICS countries. Science of the Total Environment, $678,632-638$.

Bölük, G., \& Mert, M. (2014). Fossil \& renewable energy consumption, GHGs (greenhouse gases) and economic growth: Evidence from a panel of EU (European Union) countries. Energy. https://doi.org/10.1016/j.energy.2014.07.008

Chovancová, J., \& Vavrek, R. (2019). Decoupling analysis of energy consumption and economic growth of v4 countries. Problemy Ekorozwoju, 14(1).

Cole, M. A., Rayner, A. J., \& Bates, J. M. (1997). The environmental Kuznets curve: An empirical analysis. Environment and Development Economics. https://doi.org/10.1017/S1355770X97000211

Diao, X. D., Zeng, S. X., Tam, C. M., \& Tam, V. W. (2009). EKC analysis for studying economic growth and environmental quality: a case study in China. Journal of Cleaner Production, 17(5), 541-548.

Dickey, D. A., \& Fuller, W. A. (1979). Distribution of the estimators for autoregressive time series with a unit root. Journal of the American Statistical Association, 74 (366), 427-431.

EC. (2019). The European Green Deal. In European Commission. https://doi.org/10.1017/CBO9781107415324.004

EC. (2020). Communication from the Commission to the European Parliament, the Council, the European economic and social committee and the committee of the regions: A new Circular Economy Action Plan For a cleaner and more competitive Europe. COM(2020) 98 final COM/20. https://eur-lex.europa.eu/legalcontent/EN/TXT/HTML/?uri=CELEX:52020DCoo98\&from=EN

EEA. (2021). EEA greenhouse gases - data viewer. European Environment Agency. https://www.eea.europa.eu/data-and-maps/data/data-viewers/greenhouse-gases-viewer

Gawande, K., Bohara, A. K., Berrens, R. P., \& Wang, P. (2000). Internal migration and the environmental Kuznets curve for US hazardous waste sites. Ecological Economics. https://doi.org/10.1016/So921-80o9(99)oo132-9

Grossman, G., \& Krueger, A. (1991). Environmental Impacts of a North American Free Trade Agreement. National Bureau of Economic Research. https://doi.org/10.3386/w3914

Hafner, M., \& Raimondi, P. P. (2020). Priorities and challenges of the EU energy transition: From the European Green Package to the new Green Deal. Russian Journal of Economics, 6, 374.

Halicioglu, F. (2009). An econometric study of $\mathrm{CO} 2$ emissions, energy consumption, income and foreign trade in Turkey. Energy Policy. https://doi.org/10.1016/j.enpol.2008.11.012

Hilton, F. G. H., \& Levinson, A. (1998). Factoring the environmental Kuznets curve: Evidence from automotive lead emissions. Journal of Environmental Economics and Management. https://doi.org/10.1006/jeem.1998.1023

Hobijn, B., Franses, P. H., \& Ooms, M. (1998). Generalizations of the KPSS-test for stationarity. Econometric Institute Report 9802/A.

IPCC. (2021). Climate Change 2021: The Physical Science Basis. https://www.ipcc.ch/report/sixthassessment-report-working-group-i/

Kaika, D., \& Zervas, E. (2013). The Environmental Kuznets Curve (EKC) theory-Part A: Concept, causes and the $\mathrm{CO} 2$ emissions case. Energy Policy. https://doi.org/10.1016/j.enpol.2013.07.131

Kripfganz, S., \& Schneider, D. C. (2020). Response surface regressions for critical value bounds and approximate p-values in equilibrium correction models. Oxford Bulletin of Economics and Statistics, 82 (6), 1456-1481. 
Litavcová, E., \& Chovancová, J. (2021). Economic development, co2 emissions and energy use nexusevidence from the danube region countries. Energies, 14(11). https://doi.org/10.3390/en14113165

Menegaki, A. N. (2011). Growth and renewable energy in Europe: A random effect model with evidence for neutrality hypothesis. Energy Economics, 33(2), 257-263.

Menegaki, A. N., \& Tugcu, C. T. (2016). The sensitivity of growth, conservation, feedback \& neutrality hypotheses to sustainability accounting. Energy for Sustainable Development, 34, 77-87.

Miglietta, P. P., De Leo, F., \& Toma, P. (2017). Environmental Kuznets curve and the water footprint: an empirical analysis. Water and Environment Journal. https://doi.org/10.1111/wej.12211

Odugbesan, J. A., \& Rjoub, H. (2020). Relationship among economic growth, energy consumption, $\mathrm{CO} 2$ emission, and urbanization: evidence from MINT countries. Sage Open, 10(2), 2158244020914648.

OECD. (2014). Economic policies to foster green growth.

Ozcan, B., \& Tzeremes, P. G., \& Tzeremes, N. G. (2020). Energy consumption, economic growth and environmental degradation in OECD countries. Economic Modelling, 84, 203-213.

Özokcu, S., \& Özdemir, Ö. (2017). Economic growth, energy, and environmental Kuznets curve. In Renewable and Sustainable Energy Reviews. https://doi.org/10.1016/j.rser.2017.01.059

Ozturk, I., Aslan, A., \& Kalyoncu, H. . (2010). Energy consumption and economic growth relationship: Evidence from panel data for low and middle income countries. Energy Policy, 38(8), 4422-4428.

Panayotou, T. (1994). Economic instruments for environmental management and sustainable development. United Nations Environment Programme's Consultative Expert Group Meeting.

Park, S., \& Lee, Y. (2011). Regional model of EKC for air pollution: Evidence from the Republic of Korea. Energy Policy. https://doi.org/10.1016/j.enpol.2011.06.028

Patel, S. H., Pinckney, T. C., \& Jaeger, W. K. (1995). Smallholder wood production and population pressure in East Africa: evidence of an environmental Kuznets curve? Land Economics. https://doi.org/10.2307/3146715

Pesaran, M. H., \& Shin, Y. (1999). An autoregressive distributed lag modelling approach to cointegration analysis. En S. Strom (Ed.), Econometrics and economic theory in the 2oth century: The Ragnar Frish Centennial). Cambridge: Cambridge University Press Symposium. 371-413. http://citeseerx.ist.psu.edu/viewdoc/download?doi=10.1.1.153.3246\&rep=rep1\&type=pdf

Pesaran, M. H., Shin, Y., Smith, R. J., Hin, Y., \& Smith, R. J. (2001). Bounds testing approaches to the analysis of level relationships. Journal of Applied Econometrics, 16(3), 289-326. https://doi.org/http://doi.org/10.1002/jae.616

Sapkota, P., \& Bastola, U. (2017). Foreign direct investment, income, and environmental pollution in developing countries: Panel data analysis of Latin America. Energy Economics, 64, 206-212.

Sarkodie, S. A. (2018). The invisible hand and EKC hypothesis: what are the drivers of environmental degradation and pollution in Africa?. Environmental Science and Pollution Research, 25(22), 21993-22022.

Sarkodie, Samuel Asumadu, \& Strezov, V. (2018). Empirical study of the Environmental Kuznets curve and Environmental Sustainability curve hypothesis for Australia, China, Ghana and USA. Journal of Cleaner Production. https://doi.org/10.1016/j.jclepro.2018.08.039

Selden, T. M., \& Song, D. (1994). Environmental quality and development: Is there a kuznets curve for air pollution emissions? Journal of Environmental Economics and Management. https://doi.org/10.1006/jeem.1994.1031

Shafiei, S., \& Salim, R. A. (2014). Non-renewable and renewable energy consumption and CO2 emissions in OECD countries: A comparative analysis. Energy Policy. https://doi.org/10.1016/j.enpol.2013.10.064

Shafik, N. (1994). Economic development and environmental quality: An econometric analysis. Oxford Economic Papers. https://doi.org/10.1093/oep/46.Supplement_1.757

Soytas, U., Sari, R., \& Ewing, B. T. (2007). Energy consumption, income, and carbon emissions in the United States. Ecological Economics. https://doi.org/10.1016/j.ecolecon.2006.07.009

Tiba, S., \& Omri, A. (2017). Literature survey on the relationships between energy, environment and economic growth. In Renewable and Sustainable Energy Reviews. https://doi.org/10.1016/j.rser.2016.09.113

Tiseo, I. (2021). Emissions in the EU - Statistics \& Facts. Statista. https://www.statista.com/topics/4958/emissions-in-the-european-union/

Türsoy, T. (2017). Causality between stock prices and exchange rates in Turkey: Empirical evidence from the ARDL bounds test and a combined cointegration approach. International Journal of Financial Studies, 5(1), 8. 
UN. (2021). The Sustainable Development Goals Report 2021. https://unstats.un.org/sdgs/report/2021/

United Nations. (2015). Transforming our world: the 2030 Agenda for Sustainable Development. United Nations Sustainable knowledge platform. Sustainable Development Goals. https://doi.org/https://sustainabledevelopment.un.org/post2015/transformingourworld

Vavrek, R., \& Chovancová, J. (2020). Energy performance of the European Union Countries in terms of reaching the European energy union objectives. Energies, 13(20). https://doi.org/10.3390/en13205317

Waqih, M. A. U., Bhutto, N. A., Ghumro, N. H., Kumar, S., \& Salam, M. A. (2019). Rising environmental degradation and impact of foreign direct investment: An empirical evidence from SAARC region. Journal of Environmental Management. https://doi.org/10.1016/j.jenvman.2019.05.001

Yandle, B., Bhattarai, M., \& Vijayaraghavan, M. (2004). Environmental Kuznets Curves: A Review of Findings, Methods, and Policy Implications. Research Study.

Zaim, O., \& Taskin, F. (2000). A Kuznets curve in environmental efficiency: An application on OECD countries. Environmental and Resource Economics. https://doi.org/10.1023/A:1008318605976

Zhang, X. P., \& Cheng, X. M. (2009). Energy consumption, carbon emissions, and economic growth in China. Ecological Economics. https://doi.org/10.1016/j.ecolecon.2009.05.011 